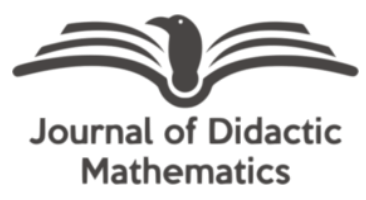

Analisis hubungan kesiapan belajar secara daring di era pandemi covid-19 terhadap hasil belajar statistika

\title{
Fitry Wahyuni*
}

Akademi Perniagaan dan Perusahaan APIPSU Medan, Sumatera Utara, Indonesia, 20123

\section{Muhammad Daut Siagian}

Universitas Islam Sumatera Utara, Jl. Sisingamangaraja, Teladan-Medan, Indonesia, 20217

*Corresponding Author:wahyunifitry17@gmail.com

\begin{abstract}
This study was motivated by the transformation of the learning process from face-to-face to online learning due to the Covid-19 pandemic. This study aims to analyze students' online learning readiness in the Covid-19 pandemic era regarding statistics learning outcomes. This research is a quantitative descriptive study using a regression research design. Data collection was carried out by providing online learning readiness questionnaires and statistical material tests to students. Based on the results of data analysis, it was found that there was a relationship between online learning readiness and student learning outcomes statistics, with the acquisition price of $F_{\text {count }}=4.195$ and a significance value of $0.048<0.05$, and $46.1 \%$ of student statistics learning outcomes were influenced by learning readiness and the rest was influenced by external factors. student learning readiness. Based on these results, it is concluded that online learning readiness affects student learning outcomes statistics, where the large influence of learning readiness is $46.1 \%$. Therefore, so that lecturers and students can maximize factors outside of learning readiness so that the achievements and objectives of the statistics course can be maximally achieved even though learning is carried out online.
\end{abstract}

Historis Artikel:

Diterima: 8 November

2020

Direvisi: 14 November

2020

Disetujui: 24 Desember

2020

\section{Keywords:}

Online; learning outcomes; statistics; covid-19

Sitasi: Wahyuni, F., \& Siagian, M. D. (2020). Analisis hubungan kesiapan belajar secara daring di era pandemi covid19 terhadap hasil belajar statistika. Journal of Didactic Mathematics, 1(3), 138-143. Doi: 10.34007/jdm.v1i3.422.

\section{PENDAHULUAN}

Dimasa pandemi Covid-19 yang merebak di hampir seluruh wilayah Indonesia menuntut Pendidikan yang seyogyanya dilaksanakan secara tatap muka, kini harus dilaksanakan melalui jarak jauh. Keputusan untuk melakukan pendidikan melalui jarak jauh tidak hanya terjadi di Indonesia saja, di negara dimana awal kemunculan pandemi ini yaitu China juga menerapkan pendidikan jarak jauh sebagai antisipasi menekan penularan. Seperti yang dikemukakan Sun, Tang, \& Zuo (2020) bahwa pandemi Covid-19 menyebabkan pengujian pendidikan jarak jauh dalam skala yang belum pernah terjadi sebelumnya. Hal ini memberikan pengalaman langsung bagi universitas China untuk memberikan pendidikan jarak jauh yang berkualitas sembari melawan pandemi.

Di Indonesia, proses pembelajaran jarak jauh dilaksanakan secara daring dengan menggunakan berbagai media seperti google classroom, google meet, zoom, whatsapp group dan media lainnya yang tersedia secara gratis maupun secara berbayar. Guru dan pendidik sebagai elemen penting dalam pengajaran melakukan transformasi pembelajaran secara besar-besaran yang belum pernah terjadi sebelumya dari proses pembelajaran tatap muka tradisional ke pembelajaran daring atau pembelajaran jarak jauh (Bao, 2020; Basilaia \& Kvavadze, 2020; Herliandry, Nurhasanah, Suban, \& Kuswanto, 2020). Proses transformasi pembelajaran ini tidak begitu memakan waktu ataupun menyulitkan mengingat perkembangan teknologi yang kian pesat. Dengan perkembangan teknologi yang tidak terbatas pada revolusi industry 4.0 saat ini memberikan dukungan terhadap 
Analisis hubungan kesiapan belajar secara daring...

proses pembelajaran jarak jauh (Herliandry et al., 2020). Lebih lanjut dijelaskan bahwa dengan teknologi yang berkembang, pembelajaran jarak jauh telah meningkat ke tingkat yang melayani gagasan pembelajaran sepanjang hayat (Korucu \& Alkan, 2011).

Pembelajaran daring saat ini dipandang merupakan salah satu solusi yang efektif untuk menghindari lonjakan jumlah korban yang terpapar Covid-19. Pembelajaran daring dimaknai sebagai pembelajaran yang menggunakan jaringan internet dengan aksesibilitas, konektivitas, fleksibilitas, dan kemampuan untuk memunculkan berbagai jenis interaksi pembelajaran (Sadikin \& Hamidah, 2020). Melalui pembelajaran daring dapat mempertemukan dosen dan mahasiswa untuk melaksanakan interaksi pembelajaran dengan bantuan internet (Kuntarto, 2017).

Namun dibalik kesiapan perangkat yang maksimal seperti kesediaan laptop/computer, handphone serta akses koneksi internet dalam menunjang pembelajaran daring, belum dapat dijadikan jaminan pencapaian hasil tujuan pembelajaran secara maksimal. Mengingat dalam pelaksanaan pembelajaran daring tidak semua materi yang diterima oleh peserta didik dapat dipahami hanya dengan cara membaca/memahami dari sumber belajar yang diberikan, seperti konsep-konsep yang ada dalam materi statistika. Statistika merupakan stepping-stone yang sangat penting untuk mempelajari matematika ke tingkat yang lebih tinggi. Statistika juga sering digunakan dalam kehidupan sehari-hari (Surya, Zulkardi, \& Somakim, 2017).

Statistika dimaknai sebagai suatu ilmu pengetahuan yang berhubungan dengan data statistik dan fakta yang benar atau suatu kajian ilmu pengetahuan dengan teknik pengumpulan data, teknik pengolahan data, teknik analisis data, penarikan kesimpulan, dan pembuatan kebijakan atau keputusan yang cukup kuat alasannya berdasarkan data dan fakta yang akurat (Fitriatien, 2017). Hal ini lah yang mendasari peneliti untuk menganalisis kesiapan belajar mahasiswa, mengingat statistika memiliki kontribusi yang sangat penting bagi mahasiswa manajemen perusahaan dalam menyusun tugas akhirnya ataupun penunjang skill dalam dunia kerja dalam melihat peluang serta mengambil keputusan berdasarkan data dan fakta.

Kesiapan belajar yang dianalisis dalam penelitian ini meliputi kesiapan belajar mahasiswa dalam mempersiapkan diri pada proses pemmbelajaran daring. Kesiapan adalah keseluruhan kondisi seseorang yang membuatnya siap untuk memberikan respon atau jawaban di dalam cara tertentu terhadap suatu situasi (Slameto, 2003). Kesiapan diduga juga memberikan pengaruh terhadap hasil belajar peserta didik (Umam \& Fakhruddin, 2016). Maka berdasarkan uraian yang melatar belakangi penelitian ini, penulis melakukan analisis hubungan kesiapan belajar mahasiswa terhadap hasil belajar statistika.

\section{METODE}

Penelitian ini merupakan penelitian deskriptif kuantitatif dengan menggunakan rancangan penelitian regresi dengan tujuan untuk mengetahui terdapat atau tidaknya pengaruh variabel independen terhadap variabel dependen. Penelitian ini dilakukan di Akademi Perniagaan dan Perusahaan APIPSU Medan. Populasi dalam penelitian ini adalah seluruh mahasiswa D3 Manajemen Perusahaan Akademi Perniagaan dan Perusahaan APIPSU Medan semester V yang berjumlah 124 orang. Metode sampling dalam penelitian ini adalah probability sampling dengan menggunakan teknik simple random sampling. Metode ini digunakan jika seluruh populasi dapat diakses dan peneliti memiliki daftar seluruh subjek dalam populasi sasaran ini. Daftar seluruh subjek dalam populasi ini disebut "kerangka sampling". Dari daftar ini, peneliti mengambil sampel secara acak dengan menggunakan metode lotere atau menggunakan daftar acak yang dibuat dikomputer. Sehingga sampel pada penelitian ini terpilih 35 orang mahasiswa (Elfil \& Negida, 2017).

Dalam penelitian ini terdapat dua variabel, yaitu variabel independen dan variabel dependen, yang menjadi variabel independen adalah "Kesiapan Belajar Secara Daring" yang kemudian disebut variabel X sedangkan yang menjadi variabel dependen adalah "Hasil Belajar Statistika" yang kemudian disebut variabel Y. Jenis data yang digunakan dalam penelitian ini adalah berupa data hasil belajar statistika dan angket kesiapan belajar mahasiswa secara daring. Instrumen yang 
digunakan dalam penelitian ini berupa tes hasil belajar statistika dan angket kesiapan belajar. Tes hasil belajar statistika disusun dengan memuat materi distribusi frekuensi, ukuran pemusatan data, ukuran penyebaran data, dan ukuran variabilitas data. Sedangkan instrument angket kesiapan belajar disusun dengan memuat delapan indikator yaitu (1) mahasiswa mengetahui tentang pembelajaran daring, (2) wali/orang tua mahasiswa mendukung pembelajaran daring, (3) mahasiswa dapat mengatur waktu dengan pembelajaran daring, (4) mahasiswa siap menggunakan media pembelajaran daring (google classroom, zoom, google meet, e-learning, dan sebagainya), (5) mahasiswa mempunyai kemampuan menggunakan IT (komputer, smartphone, dan sebagainya) dan internet, (6) mahasiswa mempunyai kemampuan belajar menggunakan pembelajaran daring, (7) mahasiswa memiliki kesulitan dalam mengakses internet, dan (8) mahasiswa dapat saling berkerjasama dalam menggunakan pembelajaran daring.

Analisis data dalam penelitian ini menggunakan teknik analisis deskriprif. Selanjutnya untuk uji persyaratan analisis data yang digunakan adalah uji normalitas dan uji linieritas. Teknik pengujian hipotesis yang digunakan adalah analisis korelasi dan regresi sederhana. Analisis dilakukan dengan menggunakan software SPSS, dengan kriteria jika nilai Sig. $<0.05$ maka $\mathrm{H}_{0}$ ditolak dan $\mathrm{H}_{\mathrm{a}}$ diterima, artinya ada pengaruh yang nyata antara kesiapan belajar daring terhadap hasil belajar statistika mahasiswa. Dan sebaliknya jika nilai Sig. $>0.05$ maka $\mathrm{H}_{\mathrm{a}}$ ditolak dan $\mathrm{H}_{0}$ diterima, artinya tidak ada pengaruh yang nyata antara kesiapan belajar daring terhadap hasil belajar statistika mahasiswa

\section{HASIL DAN PEMBAHASAN}

Tujuan utama penelitian ini adalah untuk untuk menganalisis dan mendeskripsikan hubungan kesiapan belajar secara daring terhadap hasil belajar statistika mahasiswa D3 manajemen perusahaan. Penelitian ini menggunakan metode survey untuk memperoleh data kesiapan belajar secara daring dan hasil belajar statistika mahasiswa D3 manajemen perusahaan. Secara deskriptif hasil perolehan data pada masing-masing variabel dalam penelitian ini disajikan sebagai berikut.

\section{Deskripsi Kesiapan Belajar Daring}

Data kesiapan belajar daring diperoleh melalui pemberian angket kepada mahasiswa dengan memuat delapan indikator yang menjadi landasan pengembangan angket. Delapan indikator kesiapan belajar tersebut adalah (1) mahasiswa mengetahui tentang pembelajaran daring, (2) wali/orang tua mahasiswa mendukung pembelajaran daring, (3) mahasiswa dapat mengatur waktu dengan pembelajaran daring, (4) mahasiswa siap menggunakan media pembelajaran daring (google classroom, zoom, google meet, e-learning, dan sebagainya), (5) mahasiswa mempunyai kemampuan menggunakan IT (komputer, smartphone, dan sebagainya) dan internet, (6) mahasiswa mempunyai kemampuan belajar menggunakan pembelajaran daring, (7) mahasiswa memiliki kesulitan dalam mengakses internet, dan (8) mahasiswa dapat saling berkerjasama dalam menggunakan pembelajaran daring. Pengukuran diperoleh melalui angket dengan pernyataan favorable (positif) dan pernyataan unfavorable (negatif). Secara deskriptif diperoleh data kesiapan belajar daring mahasiswa sebagai berikut.

Tabel 1. Deskripsi hasil angket kesiapan belajar daring mahasiswa

\begin{tabular}{|c|c|c|c|c|c|c|}
\hline \multicolumn{7}{|c|}{ Descriptive Statistics } \\
\hline & $\mathrm{N}$ & Range & Minimum & Maximum & Mean & Std. Deviation \\
\hline Kesiapan Belajar Daring & 35 & 11.88 & 64.53 & 76.41 & 70.1937 & 3.09960 \\
\hline Valid N (listwise) & 35 & & & & & \\
\hline
\end{tabular}

Berdasarkan tabel 1 diperoleh rata-rata hasil angket kesiapan belajar daring mahasiswa pada mata kuliah statistika sebesar 70.19, dengan nilai minimum sebesar 64.53 dan nilai maksimum sebesar 76.41. Sedangkan kategori pencapaian kesiapan belajar daring mahasiswa dijabarkan sebagai berikut. 
Analisis hubungan kesiapan belajar secara daring...

Tabel 2. Hasil Pencapaian Kesiapan Belajar Daring Mahasiswa berdasarkan Kategori

\begin{tabular}{|c|c|c|}
\hline Skor & Frekuensi & Kategori \\
\hline$X \leq 67,57$ & 7 & Sangat Rendah \\
\hline $67,57<X \leq 69,89$ & 6 & Rendah \\
\hline $69,89<X \leq 72,21$ & 9 & Sedang \\
\hline $72,21<X \leq 74,53$ & 9 & Tinggi \\
\hline$X>74,53$ & 4 & Sangat Tinggi \\
\hline
\end{tabular}

Berdasarkan data pada tabel 2 dapat dilihat bahwa kesiapan belajar daring mahasiswa pada mata kuliah statistika cukup baik dengan persentase kesiapan belajar daring dengan kategori minimal sedang sebesar $62,86 \%$. Hal ini menunjukkan bahwa mahasiswa memiliki kesiapan belajar yang cukup dengan pembelajaran daring dimasa pandemi.

\section{Deskripsi Hasil Belajar Statistika}

Data hasil belajar statistika mahasiswa D3 manajemen perusahaan diperoleh dengan memberikan tes yang memuat materi statistika yang telah dipelajari oleh mahasiswa selama proses pembelajaran daring. Berikut deskripsi tes hasil belajar statistika mahasiswa D3 manajemen perusahaan.

Tabel 3. Deskripsi Hasil Belajar Statistika Mahasiswa

\begin{tabular}{|c|c|c|c|c|c|c|}
\hline \multicolumn{7}{|c|}{ Descriptive Statistics } \\
\hline & $\mathrm{N}$ & Range & Minimum & Maximum & Mean & Std. Deviation \\
\hline Hasil Belajar Statistika & 35 & 27.65 & 68.09 & 95.74 & 82.4314 & 7.04357 \\
\hline Valid N (listwise) & 35 & & & & & \\
\hline
\end{tabular}

Berdasarkan tabel 3 diperoleh rata-rata tes hasil belajar statistika mahasiswa sebesar 82.43, dengan nilai minimum sebesar 68.09 dan nilai maksimum sebesar 95.74.

\section{Hubungan Kesiapan Belajar Daring terhadap Hasil Belajar Statistika}

Tujuan utama penelitian ini adalah untuk untuk menganalisis hubungan kesiapan belajar secara daring terhadap hasil belajar statistika mahasiswa D3 manajemen perusahaan di era pandemi. Untuk mengetahui hubungan antara kesiapan belajar daring dengan hasil belajar statistika mahasiswa dilakukan analisis korelasi dan regresi sederhana. Adapun hasil pengujian terhadap hubungan kedua variable tersebut disajikan pada tabel berikut.

Tabel 4. Hasil Uji Koefisien Regresi

\begin{tabular}{llrrrrr}
\multicolumn{7}{c}{ ANOVA $^{\mathbf{a}}$} \\
\hline Model & & Sum of Squares & Df & Mean Square & F & Sig. \\
\hline \multirow{2}{*}{1} & Regression & 235.112 & 1 & 235.112 & 4.195 & $.048^{\mathrm{b}}$ \\
& Residual & 2129.769 & 33 & 56.047 & & \\
& Total & 2364.881 & 34 & & & \\
\hline
\end{tabular}

a. Dependent Variable: Hasil_Belajar_Statistika

b. Predictors: (Constant), Kesiapan_Belajar_Daring

Hasil pada tabel 4 menunjukkan koefisien regresi signifikan karena diperoleh harga $F_{\text {hitung }}=$ 4.195 dan nilai signifikansi $0,048<0,05$, artinya ada pengaruh positif antara kesiapan belajar daring terhadap hasil belajar statistika mahasiswa. Dengan bekal kesiapan belajar yang baik dalam pembelajaran daring maka akan sangat mempengaruhi perolehan hasil belajar mahasiswa khususnya hasil belajar statistika mahasiswa. Selanjutnya untuk mengetahui besarnya pengaruh kesiapan belajar daring terhadap hasil belajar statistika mahasiswa dapat dilihat berdasarkan hasil uji korelasi berikut ini. 
Tabel 5. Hasil Uji Korelasi

\begin{tabular}{lccccr}
\multicolumn{4}{c}{ Model Summary } \\
\hline Model & $\mathrm{R}$ & R Square & Adjusted R Square & Std. Error of the Estimate & 7.48642 \\
\hline 1 & $.315^{\mathrm{a}}$ & .461 & .056 & &
\end{tabular}

Pada tabel model summary pada tabel 5 , kolom $\mathrm{R}$ Square menunjukkan bahwa nilai yang diperoleh sebesar 0.461 artinya sumbangan pengaruh variabel kesiapan belajar daring terhadap hasil belajar statistika sebesar $46.1 \%$ sedangkan sisanya dipengaruhi oleh variabel lain selain variabel kesiapan belajar daring. Sedangkan untuk pengujian regresi pada kedua variabel yaitu kesiapan belajar daring dan hasil belajar statistika mahasiswa dapat dilihat pada tabel 6 berikut ini.

Tabel 6. Hasil Uji Regresi Sederhana

Coefficients $^{\mathbf{a}}$

\begin{tabular}{|c|c|c|c|c|c|c|}
\hline \multirow{2}{*}{\multicolumn{2}{|c|}{ Model }} & \multicolumn{2}{|c|}{ Unstandardized Coefficients } & \multirow{2}{*}{$\begin{array}{l}\text { Standardized } \\
\text { Coefficients } \\
\text { Beta }\end{array}$} & \multirow[t]{2}{*}{$\mathrm{t}$} & \multirow[t]{2}{*}{ Sig. } \\
\hline & & $\mathrm{B}$ & Std. Error & & & \\
\hline \multirow{2}{*}{1} & (Constant) & 48.917 & 4.068 & & 5.328 & .000 \\
\hline & Kesiapan_Belajar_Daring & .193 & .338 & .315 & 1.048 & .048 \\
\hline
\end{tabular}

a. Dependent Variable: Hasil_Belajar_Statistika

Berdasarkan output tabel Coefficients diperoleh persamaan regresi linear sederhana: $\hat{Y}=$ $48.917+0.193 X$. Maka berdasarkan hasil pengolahan data di atas dengan perolehan nilai thitung sebesar 1.048 dengan nilai signifikansi sebesar $0,048<0,05$. Maka dalam hal ini $\mathrm{H}_{0}$ ditolak, yang berarti ada pengaruh yang nyata antara kesiapan belajar daring terhadap hasil belajar statistika mahasiswa.

Kesiapan mahasiswa dalam proses pembelajaran secara daring menjadi salah satu aspek yang harus diperhatikan, mengingat belajar daring merupakan suatu hal yang tidak biasa dilakukan pada saat kondisi sebelum adanya pandemi. Kesiapan belajar daring pada saat ini tidak menyulitkan dalam pelaksanaannya mengingat perkembangan teknologi yang begitu pesat disamping itu juga hampir 100\% mahasiswa memiliki fasilitas yang dapat menunjang kegiatan belajar daring. Hal ini sejalan pandangan (Hussin, 2018) bahwa the advancement of technology enables the learning of certain domains effectively, thus making more room for acquiring skills that involve buman knowledge and face-to-face interaction. Disamping fasilitas, juga dibutuhkan kemampuan mahasiswa dalam beradaptasi sehingga dapat memaksimalkan proses pembelajaran secara daring, hal ini sejalan dengan pandangan Wannemacher bahwa kemampuan adaptasi yang baik sangat menentukan efektivitas pembelajaran daring (Setiaji \& Dinata, 2020).

Berbagai studi yang terkait dengan pengaruh kesiapan belajar juga menunjukkan hasil serupa, hasil studi Umam \& Fakhruddin (2016) menunjukkan bahwa ada pengaruh kesiapan belajar terhadap hasil belajar, kesiapan belajar peserta didik akan berpengaruh terhadap hasil belajar peserta didik, maka jika seorang peserta didik memiliki kesiapan belajar yang baik maka peserta didik tersebut juga akan memiliki hasil belajar yang baik pula. Studi yang dilakukan Effendi (2017) juga menunjukkan hubungan yang signifikan antara kesiapan peserta didik terhadap hasil belajar yang dicapainya.

\section{KESIMPULAN}

Berdasarkan hasil dan temuan penelitian diperoleh skor $F_{\text {hitung }}$ sebesar 4.195, dengan nilai Sig. $0.048<0.05$. Sehingga hipotesis nol $\left(\mathrm{H}_{0}\right)$ ditolak, atau dapat disimpulkan bahwa terdapat hubungan/pengaruh kesiapan belajar daring terhadap hasil belajar statistika mahasiswa. Sedangkan pada tabel R square diperoleh skor sebesar 0.461, yang artinya kesiapan belajar daring memberikan pengaruh sebesar $46.1 \%$ terhadap hasil belajar statistika mahasiswa dan sisanya dipengaruhi oleh 
Analisis hubungan kesiapan belajar secara daring...

faktor lain diluar kesiapan belajar daring. Mahasiswa diharapkan memiliki perhatian belajar yang baik dengan cara menyiapkan kondisi baik secara fisik maupun psikis sebelum mengikuti pembelajaran, selain itu mahasiswa juga harus memotivasi dirinya untuk selalu semangat dalam belajar agar mendapatkan hasil belajar yang maksimal serta dapat mengatur waktunya dalam pelaksanaan daring. Dosen sebagai pendidik diharapkan juga mampu menghadirkan sumber belajar yang efektif sesuai dengan kebutuhan mahasiswa sehingga dapat memberikan pemahaman yang baik bagi mahasiswa dalam memahami materi dan konsep statistika.

\section{DAFTAR PUSTAKA}

Bao, W. (2020). COVID-19 and online teaching in higher education: A case study of Peking University. Human Behavior and Emerging Technologies, 2(2), 113-115. https://doi.org/10.1002/hbe2.191

Basilaia, G., \& Kvavadze, D. (2020). Transition to Online Education in Schools during a SARSCoV-2 Coronavirus (COVID-19) Pandemic in Georgia. Pedagogical Research, 5(4). https://doi.org/10.29333/pr/7937

Effendi. (2017). Hubungan readiness (kesiapan) belajar siswa dengan hasil belajar fisika siswa kelas X SMK. JPF (Jurnal Pendidikan Fisika), 5(1), 15-24.

Elfil, M., \& Negida, A. (2017). Sampling methods in clinical research; an educational review. Emergency, 5(1), 1-3. https://doi.org/10.22037/emergency.v5i1.15215

Fitriatien, S. R. (2017). Pengantar statistika untuk penelitian: Suatu kajian. Jurnal Buana Pendidikan, 12(23), 49-55.

Herliandry, L. D., Nurhasanah, N., Suban, M. E., \& Kuswanto, H. (2020). Pembelajaran Pada Masa Pandemi Covid-19. JTP - Jurnal Teknologi Pendidikan, 22(1), 65-70. https://doi.org/10.21009/jtp.v22i1.15286

Hussin, A. A. (2018). Education 4.0 made simple: Ideas for teaching. International Journal of Education and Literacy Studies, 6(3), 92-98. https://doi.org/http://dx.doi.org/10.7575/aiac.ijels.v.6n.3p.92

Korucu, A. T., \& Alkan, A. (2011). Differences between m-learning (mobile learning) and elearning, basic terminology and usage of $\mathrm{m}$-learning in education. Procedia - Social and Behavioral Sciences, 15, 1925-1930. https://doi.org/10.1016/j.sbspro.2011.04.029

Kuntarto, E. (2017). Keefektifan model pembelajaran daring dalam perkuliahan bahasa Indonesia di perguruan tinggi. Journal Indonesian Language Education and Literature, 3(1), 53-65. Retrieved from http://www.syekhnurjati.ac.id/jurnal/index.php/jeill/\%0APEMBELAJARAN

Sadikin, A., \& Hamidah, A. (2020). Pembelajaran daring ditengah wabah Covid-19. BIODIK: Jurnal Ilmiah Pendidikan Biologi, 6(2), 214-224. https://doi.org/10.17509/t.v6i2.20887

Setiaji, B., \& Dinata, P. A. C. (2020). Analisis kesiapan mahasiswa jurusan pendidikan fisika menggunakan e-learning dalam situasi pandemi Covid-19. Jurnal Inovasi Pendidikan IP A, 6(1), 59-70. https://doi.org/10.21831/jipi.v6i1.31562

Slameto. (2003). Belajar dan faktor-faktor yang mempengarubinya. Jakarta: Rineka Cipta.

Sun, L., Tang, Y., \& Zuo, W. (2020). Coronavirus pushes education online. Nature Materials, 19(6), 687. https://doi.org/10.1038/s41563-020-0678-8

Surya, A., Zulkardi, Z., \& Somakim, S. (2017). Desain pembelajaran statistika menggunakan konteks mal di kelas V. Jurnal Elemen, 3(2), 149-165. https://doi.org/10.29408/jel.v3i2.344

Umam, K. A., \& Fakhruddin. (2016). Pengaruh kesiapan belajar terhadap hasil belajar peserta didik program paket C. Journal of Non-Formal Education, 2(2), 162-167. 